\title{
SEISMIC MICROZONATION OF BANDUNG BASIN FROM MICROTREMOR HORIZONTAL-TO-VERTICAL SPECTRAL RATIOS (HVSR)
}

\author{
Bayu Pranata ${ }^{1,2}$, Tedi Yudistira ${ }^{3}$, Erdinc Saygin ${ }^{5}$, Phil R. Cummins ${ }^{4}$, Sri Widiyantoro ${ }^{3}$, Budi \\ Brahmantyo $^{6}$, Zulfakriza ${ }^{3}$, \\ 1. Earth science Study Program, Institute of Technology Bandung, Indonesia \\ 2. Badan Meteorologi, Klimatologi dan Geofisika, Jakarta, Indonesia \\ 3. Global Geophysics Research Group, FTTM, Institute of Technology Bandung, Indonesia \\ 4. Research School of Earth Science, Australian National University, Canberra, ACT, Australia \\ 5. Commonwealth Scientific and Industrial Research Organisation (CSIRO), Perth, Australia, \\ School of Physics\&Astrophysics, University of Western Australia, Perth, Australia \\ 6. Applied Geology Research Group, FITB, Institute of Technology Bandung, Indonesia \\ E-mail: bayu_bmg@yahoo.com
}

\begin{abstract}
Bandung is located on a thick sedimentary basin, which is mainly composed of volcanic rocks and the depositional remnants of an ancient lake. The high population density and vital infrastructure, surrounding by potential sources of earthquakes make Bandung vulnerable to earthquake impact. To study the seismic response of Bandung, a microzonation study is needed so as to facilitate disaster risk assessment and mitigation. The parameters which are mapped for the purpose of microzonation are the distribution of the dominant frequency $\left(\mathrm{F}_{0}\right)$, the amplification factor (Am) and seismic susceptibility $(\mathrm{Kg})$. We use the HVSR analysis method with microtremor/ambient seismic noise data. The microtremor data were taken from 58 measurement points from the Bandung Seismic Experiment network run from March to October 2014 in the Bandung basin and surrounding areas. The results show that the dominant peak frequency in the studied area ranges from $0.195 \mathrm{~Hz}$ to $7.016 \mathrm{~Hz}$, amplification (A) spans from 1.6 to 11.3 , and the value of the seismic susceptibility index $\left(\mathrm{K}_{\mathrm{g}}\right)$ ranges from 0.6 to 245.6. The spatial distribution of seismic susceptibility index indicates that almost all areas of the Bandung basin have high susceptibility to earthquake hazard. The highest susceptibility is found in the eastern part of the Bandung basin that includes Bojongsoang, Rancaekek, Ciparay, Rancasari, and Majalaya, while the lower susceptibility zones are scattered in the hills and mountains around the basin of Bandung.
\end{abstract}

Key words: Microzonation, ambient seismic noise, dominant frequency, amplification factor, seismic susceptibility index.

\section{Introduction}

Geographically, the city of Bandung is in the middle of the island of West Java in West Java Province in a basin surrounded by a volcanoes known as the Bandung Basin. This basin covers an area of up to 348,786 Ha with an average height of 665 meters. In the past, the Bandung Basin was a lake (Dam and Suparan, 1992). The basin fill is mainly composed of volcanic tuff and ancient lake sediments. The seismic activity in West Java is dominated by earthquakes originating from the subduction of the Indo-Australian plate under Eurasia. However, earthquakes from local faults in the mainland are increasing the potential of seismic hazard. Among the potential sources of local earthquakes are the Cimandiri, the Lembang, Tomo, and Bumi Ayu Faults, although there are likely other faults that some have not been well identified. 
The structural damage due to earthquakes and shaking intensity is influenced by geological conditions and local soil conditions (Seed and Schnabel, 1972). Soft sedimentary rocks are known to amplify ground motion during an earthquake and therefore damage is more severe for strucures on soft soil than on hard rock (Tuladhar, 2002).. Previous studies have shown that local site effects can be estimated using horizontal microtremor analysis of the Horizontal-to-Vertical Spectral Ratio (HVSR, Nakamura et al. (2000), Huang and Tseng (2002), Nakamura (2008), Daryono, (2011)). HVSR measures the predominant ground natural frequency (F0), amplification value (Am) and seismic susceptibility $\left(\mathrm{K}_{\mathrm{g}}\right)$. Based on this, our study aims to understand the characteristics of local site effects of the Bandung Basin region by analysing the natural frequency of sediment layers, the value of earthquake shock amplification and seismic susceptibility index by performing microtremor analysis of HVSR method applied to recordings of ambient seismic noise.

Nakamura $(2000,2008)$ showed in his research in Marina District, San Francisco, that a high seismic susceptibility index is present in areas composed of alluvial materials, but its value decreases in areas of harder rocky hills. Buildings in the Marina District, a coastal area of alluvial sediments with a high seismic susceptibility index ,were seriously damaged in the wake of the 1989 Loma Prieta earthquake. Another study with similar results was done by Gurler et al. (2000), who showed that for the 1985 Mexican Micoachan earthquake, areas with high susceptibility index near rivers, reclamation areas, and swamps,sustained high damage. Similarly, the work of Daryono et al. (2009), found that the distribution of earthquake damage during the Yogyakarta May 27, 2006 earthquake is correlated with $\mathrm{K}_{\mathrm{g}}$ distribution. Also high $\mathrm{K}_{\mathrm{g}}$ can be used to predict the presence of liquefaction phenomena. Huang and Tseng (2002) found that high $\mathrm{Kg}$ was correlated with liquefaction during the Taiwan Chi-Chi earthquake in 1999. Similarly, Daryono et al. (2009) also states that the phenomenon of earthquake liquefaction during the Yogyakarta 2006 earthquake ocurred areas of high $\mathrm{K}_{\mathrm{g}}$ index along the Opak river.

\section{MICROTREMOR HORIZONTAL TO VERTICAL SPECTRAL RATIO (HVSR)}

\section{A. Data}

The data were collected from broadband seismometers deployed over 58 recording stations with a sampling rate of $250 \mathrm{~Hz}$. The seismometer network was operated from March to October 2014, where stations were deployed in residential and school buildings. The seismometer distribution covers the basin area of Bandung as well as in the south, and also includes Mount Tangkuban Perahu and the Lembang Fault in the north, with an inter-station spacing of approximately $3 \mathrm{~km}$ (Figure 3). The data logger was always synchronized with a GPS receiver so that the timing and location are very accurate. The recorded data is a time series waveform in miniSEED format (Standard Exchange of Earthquake Data).

\section{B. Methods}

The HVSR technique estimates the ratio of Fourier amplitude spectra between the horizontal and vertical components of ambient noise vibrations, which is usually peaked at a resonant frequency that chacterises the area under study. We calculate HVSR by using the GEOPSY software (www.geopsy.org) for the frequency range 0.2 to $20 \mathrm{~Hz}$, using a $50 \mathrm{~s} \mathrm{time} \mathrm{window} \mathrm{and} \mathrm{removing} \mathrm{windows} \mathrm{of} \mathrm{time} \mathrm{contaminated} \mathrm{by} \mathrm{transient} \mathrm{noise.} \mathrm{The} \mathrm{interpretation}$ of the $\mathrm{H} / \mathrm{V}$ curve is done in accordance with international guidelines of SESAME (see SESAME Europe project (2004)). According to this,, we first verify the reliability of the curve (that is, a sufficient number of windows and a significant cycle for a certain f0, low scatter is acceptable between all windows with a certain frequency range around f0) and we check clarity and reliability of the HVSR peak (ie, fulfillment of amplitude and stability criteria). The HVSR is defined as a function of frequency $f$, in the equation below: 


$$
\operatorname{HVSR}(\mathrm{f})=\sqrt{\left(\frac{\operatorname{Pns}(f)+\operatorname{Pew}(\mathrm{f}))}{\operatorname{Pud}(\mathrm{f})}\right.}
$$

With Pud(f) is the Fourier power spectrum of the vertical / upp-down component seismogram, Pns(f) is the Fourier power spectrum of the North-South component seismogram, Pew(f) is the Fourier power spectrum of the East-West component.

From the HVSR curve, we obtain information in the form of predominant or natural frequency and soil amplification. HVSR is a curve thart incorporates both horizontal and vertical components. The predominant frequency is related to the thickness of the sediment layer (Daryono et al., 2009). The high predominant frequency indicates that the layer is composed of hard rock, and the low predominant frequency indicates that the layer is composed of soft rock. As pointed out also by Parolai et al. (2001) that the deeper the bedrock the lower the dominant frequency. Conversely the shallower the bedrock, the higher the predominant frequency. The result of predominant frequency extraction and amplification of the HVSR curve for each point is used to estimate the seismic susceptibility index $\left(\mathrm{K}_{\mathrm{g}}\right)$.

According to Nakamura (2008), the seismic susceptibility is an index that describes the level of surface layer susceptibility to deformation during earthquakes. The seismic susceptabilty index is inversely proportional to the dominant frequency, and is directly proportional to the amplification factor. If an area has a higher seismic susceptibility index then the area is more vulnerable to earthquakes. If an area has smaller seismic susceptibility indexes, the area is more resistant to earthquake hazards. Nakamura et al. (2000) gives the seismic susceptabilty index equation $\left(\mathrm{K}_{\mathrm{g}}\right)$ as in the following equation:

$$
\mathrm{Kg}=\mathrm{Am}^{2} / \mathrm{f0}
$$

With $\mathrm{K}_{\mathrm{g}}$ is the seismic susceptance index, Am is the peak value of the HVSR curve and f0 is the predominant frequency.

Following are the steps of data processing:

1. Quality control and sorting data.

2. Daily data file input on the second day after installation (assuming the sensors has been stabilized) and displaying the seismic data in miniSEED format using Geopsy software.

3. Cut daily data which is then used in data processing. HVSR is measured using nighttime data from $17 \mathrm{~h} 00 \mathrm{~m} 00.0 \mathrm{~s}$ to $23 \mathrm{~h} 00 \mathrm{~m} 00.0 \mathrm{~s}$ (6 hours duration) (Figure 1). Use of nighttime data selection is to reduce unwanted noise such as transient noise and anthropogenic noise.

4. HVSR analysis with $\mathrm{H} / \mathrm{V}$ toolbox of Geopsy.

5. Perform frequency filtering with bandpass filter and use anti-triggering algorithm.

6. Fourier spectrum analysis that serves to change the initial microtremor data in the form of time domain to the frequency domain. Fast Fourier Transform (FFT) algorithm, In spectral analysis, each recording length is split into 20 to 40 second non-overlapping windows. 
7. We use a smoothing function (Konno and Ohmachi, 1998) with a bandwidth coefficient of 40 . The average amplitude spectrum for each component is calculated from the selected window.

8. Determine the average HVSR from the ratio of horizontal components and vertical components.

9. Determine the dominant frequency (F0) and amplification factor (A0) (Figure 2).

10. Determine the seismic susceptibility index $\left(\mathrm{kg}_{\mathrm{g}}\right)$.

11. Make each of the contours F0, A0 and $\mathrm{K}_{\mathrm{g}}$ by interpolating from each measurement point using Quantum GIS software.

12. Conduct analysis and interpretation of each microzonation map F0, $\mathrm{A} 0$ and $\mathrm{K}_{\mathrm{g}}$

\section{Results}

Based on Figure 3 obtained from the result of HVSR analysis for the research area, it can be seen that dominant frequencies vary but generally the most red color contours are near the center of the basin. The red contour shows the lowest dominant frequency ranging from 0.195 to $1.68 \mathrm{~Hz}$. The distribution of predominant frequency shown on the map correlates with the topography of the Bandung basin. Very low dominant frequency are in low topography areas and very high frequency are at high topography areas. This shows conformity with the distribution of sediment layers where in low topography areas the soft sediment layer thickens so that the dominant frequency is very low and vice versa. The yellow contours show high dominant frequency more widely spread on the slopes of Bandung basin. Based on the land classification according to Kanai (1983), it is known that the region is composed of alluvial sediments with soil types III and IV. Type III soil in general consists of sandy-gravel, sandy hard clay, and loam, with sediment thickness ranges from 10 to 30 meters. Type IV soil is generally formed from delta sedimentation, top soil, mud with a depth of $30 \mathrm{~m}$ or more, and thick sediment thickness.

The distribution of peak HVSR values (amplification or A) varies in the range between 1.6 and 11.3. The highest amplification is at the point BNA17 in the Cipatat region, while the lowest is at point BNA51 in the Cisarua region. The distribution of amplification in the eastern parts of the Bandung basin such as Bojongsoang, Ciparay and Rancaekek tends to have a relatively larger amplification compared to the western part (Figure 4). Areas with high amplification factor tend to have a large resonance potential in the area, and vice versa with areas with low amplification factor (Daryono et al., 2009). When associated with the dominant frequency, the variation of amplification is not always correlated with the thickness of the sediment.

The distribution of seismic susceptibility index $\left(\mathrm{K}_{\mathrm{g}}\right)$ in the Bandung basin (Figure 4) ranges from 0.6 to 245.6. In general, the distribution of relatively high values corresponds to the distribution of high amplification in the East basin of Bandung. These areas include Bojongsoang, Rancaekek, Ciparay, Rancasari, and Majalaya. The highest in the western part of Bandung basin is at the point BNA54 in Padalarang adjacent to the Saguling reservoir. Low seismic susceptibility is generally located in areas with higher topography or hills.

In general the variation of seismic susceptibility obtained from this study correlates with amplification.

\section{Conclusions and Expected impacts}

The predominant frequency (F0) of the microtremor analysis is an indicator of sediment thickness and soil classification. The predominant frequency distribution (F0) corresponds to the topography of the Bandung basin basement surface where, the low dominant frequency correspons to a thick layer of sediment and vice versa.

The highest amplification (Am) distribution is in the East of the basin Bandung. High amplification indicating 
there is a high resonance potential. Saution needs to be exercised in an area with high amplification, because an earthquake has higher potential to damage the buildings in such areas. The seismic susceptibility has been proven in some studies correlate with the patterns of damage caused by earthquakes. Areas with high seismic susceptibility index $\left(\mathrm{K}_{\mathrm{g}}\right)$ such as Bojongsoang, Rancaekek, Ciparay, Rancasari, Majalaya and Cipatat have high damage potential should an earthquake occur.

\section{Acknowledgement}

We would like to express our gratitude to the Research School of Earth Sciences, The Australian National University for permitting us to use their seismographs for this research.

\section{References}

1. Dam, M. A. C., Suparan, P., Nossin, J. J., Voskuil, R. P. G. A. \& G. T. L. Group (1996) A chronology for geomorphological developments in the greater Bandung area, West-Java, Indonesia. J. Southeast Asian Earth Sci. 14(1-2), 101-115.

2. Daryono, Sutikno, Sartohadi, J., Dulbahri, Brotopuspito, K.S. (2009): Local site effect at Bantul Graben based on Microtremor measurements. International Conference Earth Science and Technology. Phonix Hotel, Yogyakarta.

3. Daryono (2011): Indeks Kerentanan Seismik Berdasarkan Mikrotremor pada Setiap Satuan Bentuk lahan di Zona Graben Bantul, Daerah Istimewa Yogyakarta, Disertasi, Program Pascasarjana Fakultas Geografi, Universitas Gadjah Mada, Yogyakarta.

4. Huang, H. dan Tseng, Y. (2002): Characteristics of soil liquefaction using H/V of microtremor in Yuan-Lin area, Taiwan. TAO, Vol. 13, No. 3, 325-338.

5. Konno dan Ohmachi (1998): Ground-Motion Characteristics Estimated from Spectral Ratio between Horizontal and Vertical Components of Microtremor. Bulletin of the Seismological Society of America.

6. Nakamura, Y, (2000): Clear Identification of Fundamental Idea of Nakamuras Technique and Its Application. Proc XII World Conf. Earthquake Engineering. New Zealand, 2526.

7. Nakamura, Y, (2008): On The H/V Spectrum. The 14 th World Conference On Earthquake Enggineering. Oktober 12-17, 2008, Beijing, China.

8. Parolai, S., Bormann, P., Milkereit, C. (2001): Assessment of the Natural Frequency of the Sedimentary Cover in the Cologne Area (Germany) Using Noise Measurement. Journal of Earthquake Engineering, 5, 541-564.

9. Seed, H.B,. dan Schnabel, P.B. (1972): Soil and Geological effects on site response during earthquakes”, Proc. first International Conference on Microzonation for Safer Construction-Research and Application, vol. 1. pp 61-74.

10. Sesame European Research Project (2004): Guidelines For The Implementation of The H/V Spectral Ratio 
Technique on Ambient Vibrations, Europen Commision Research General Directorate.

11. Tuladhar, R., Yamazaki, F., Warnitchai, P. and Saita, J. (2004): Seismic microzonation of the greater Bangkok area using microtremor observations. Earthquake Engng. Struct. Dyn., 33: 211225. doi:10.1002/eqe.345.

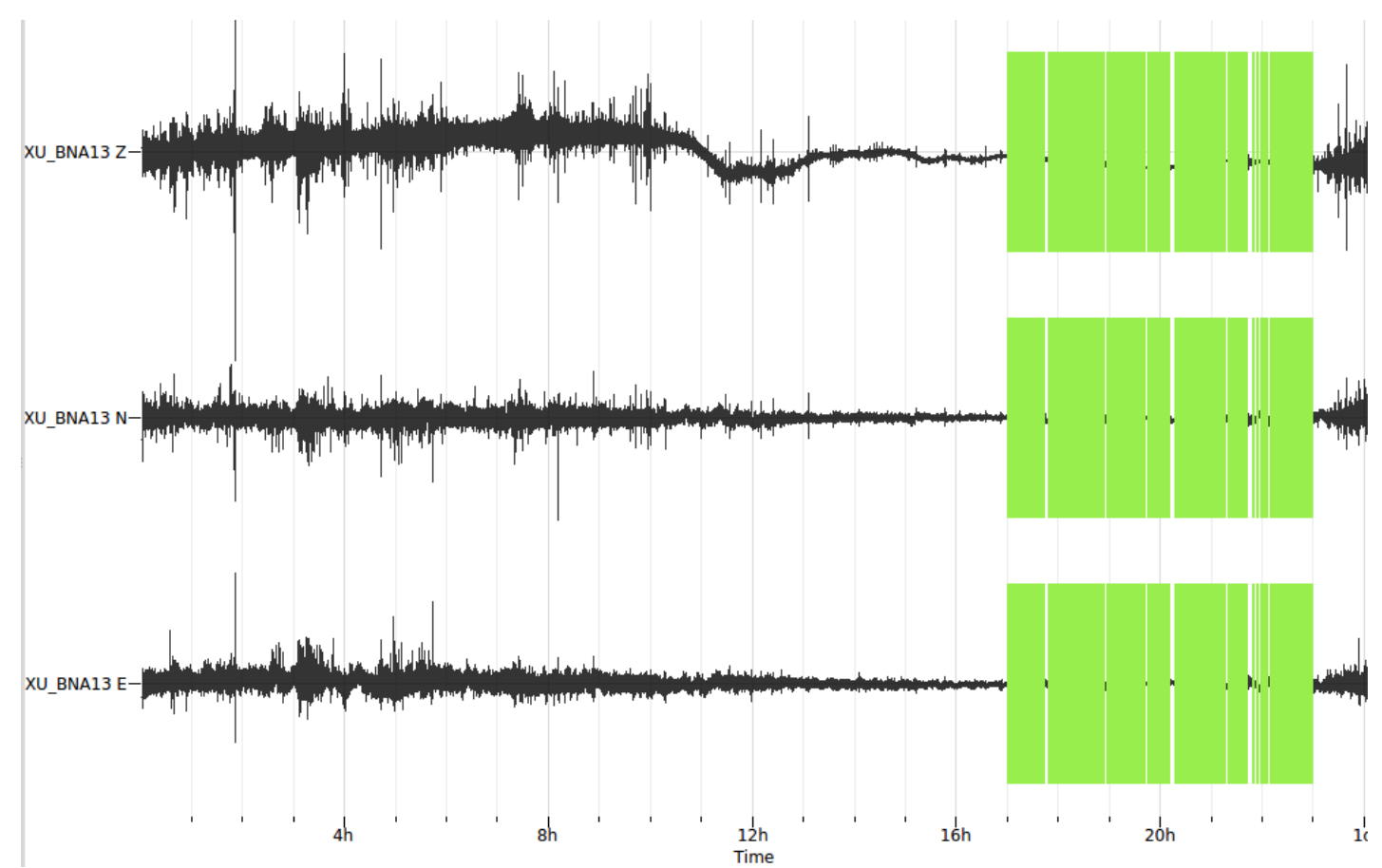

Figure 1. 1 day seismic data record on March 23, 2014 at BNA13 station and night time window selection (17:00 to 23:00 UTC) 


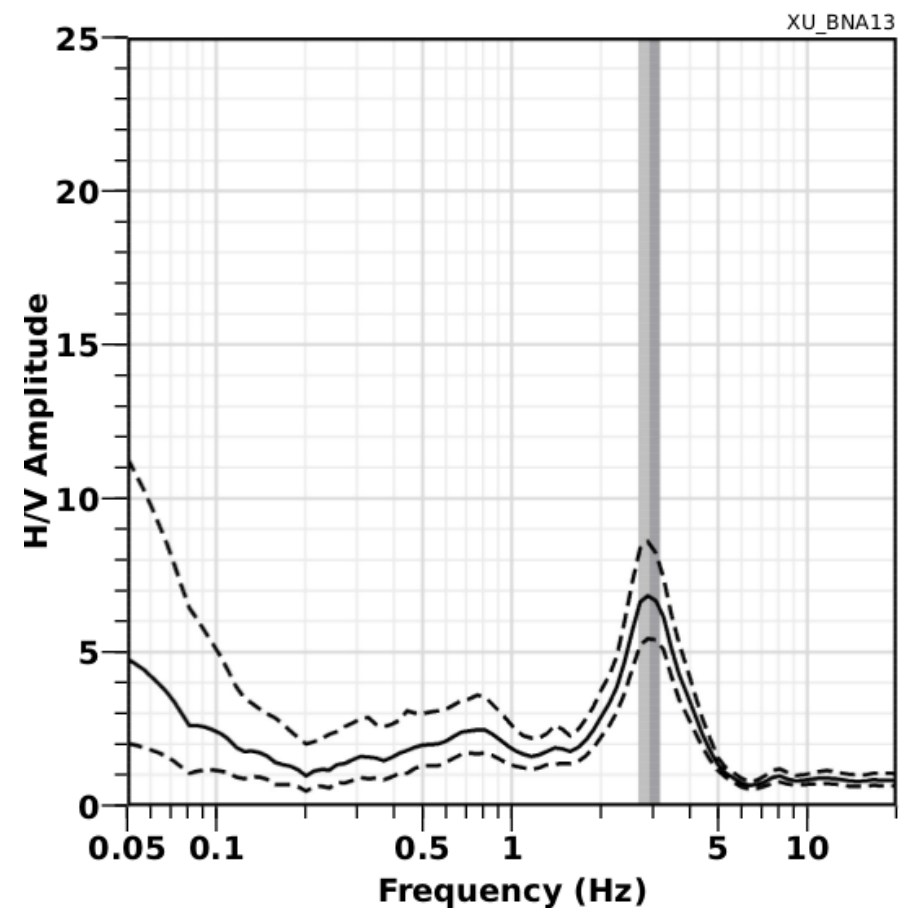

Figure 2. The spectrum of the HVSR curve to the frequency at BNA13 


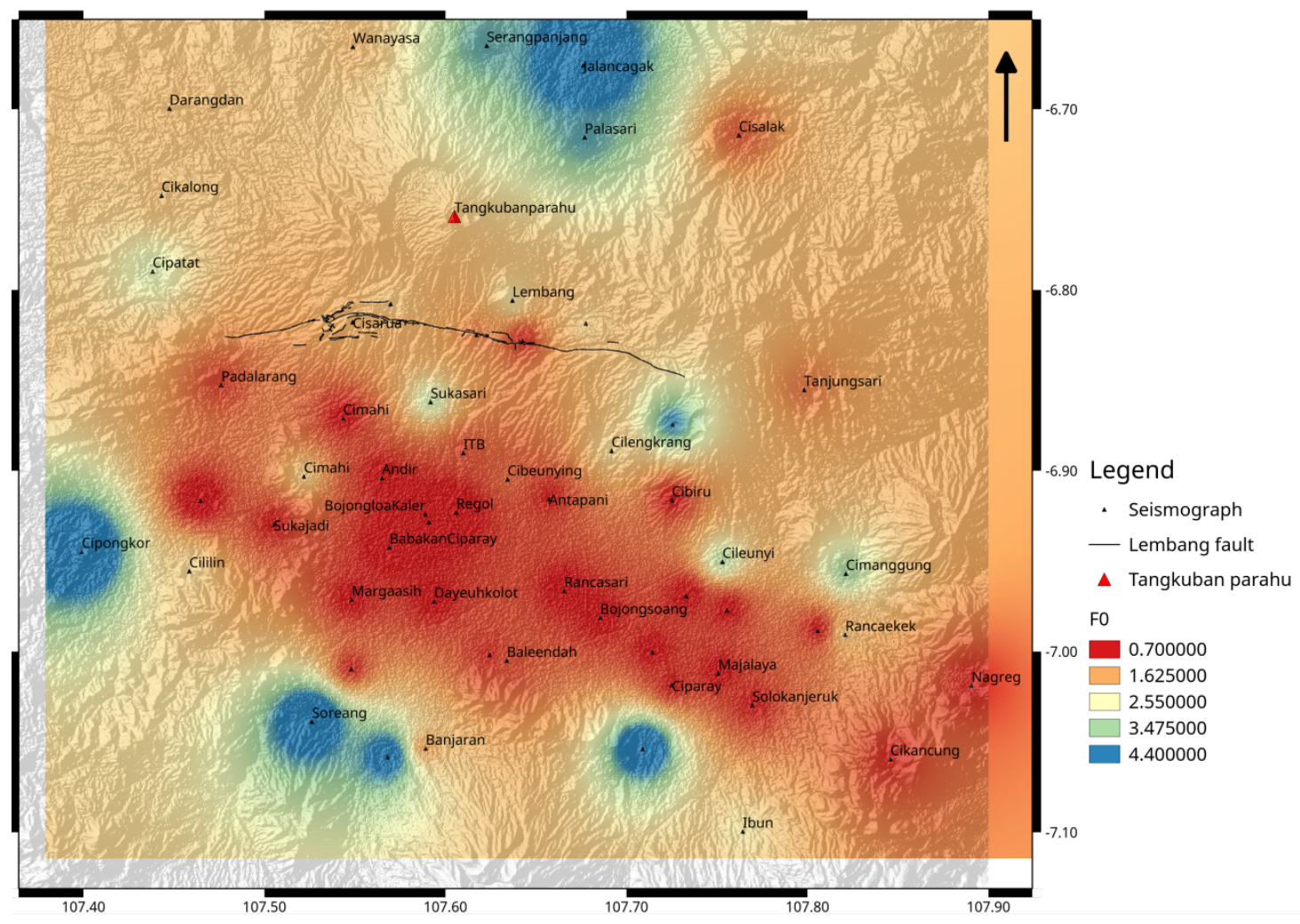

Figure 3. The dominant frequency map (F0) of the Bandung basin area 


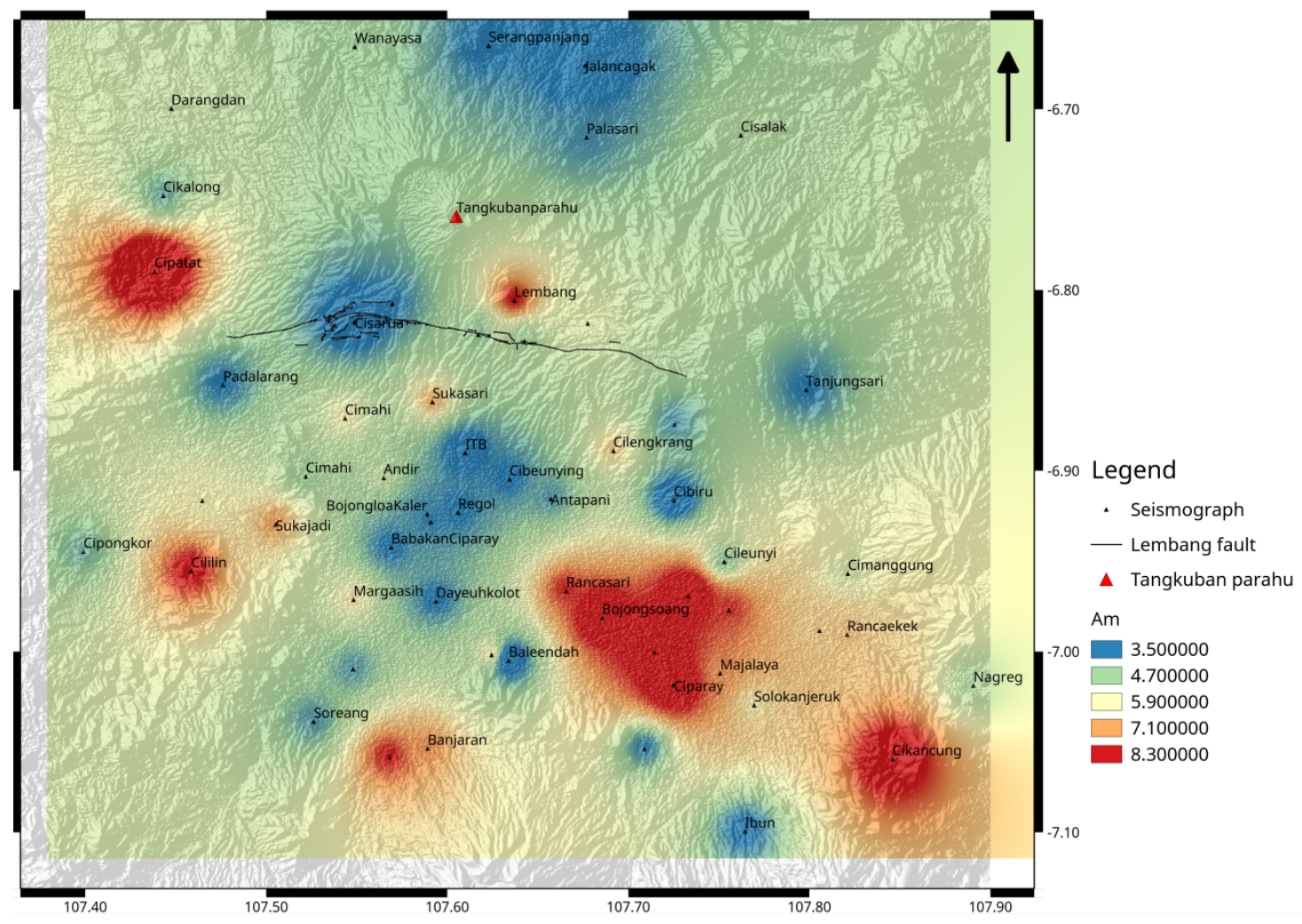

Figure 4. Map of amplification (Am) in Bandung basin area 


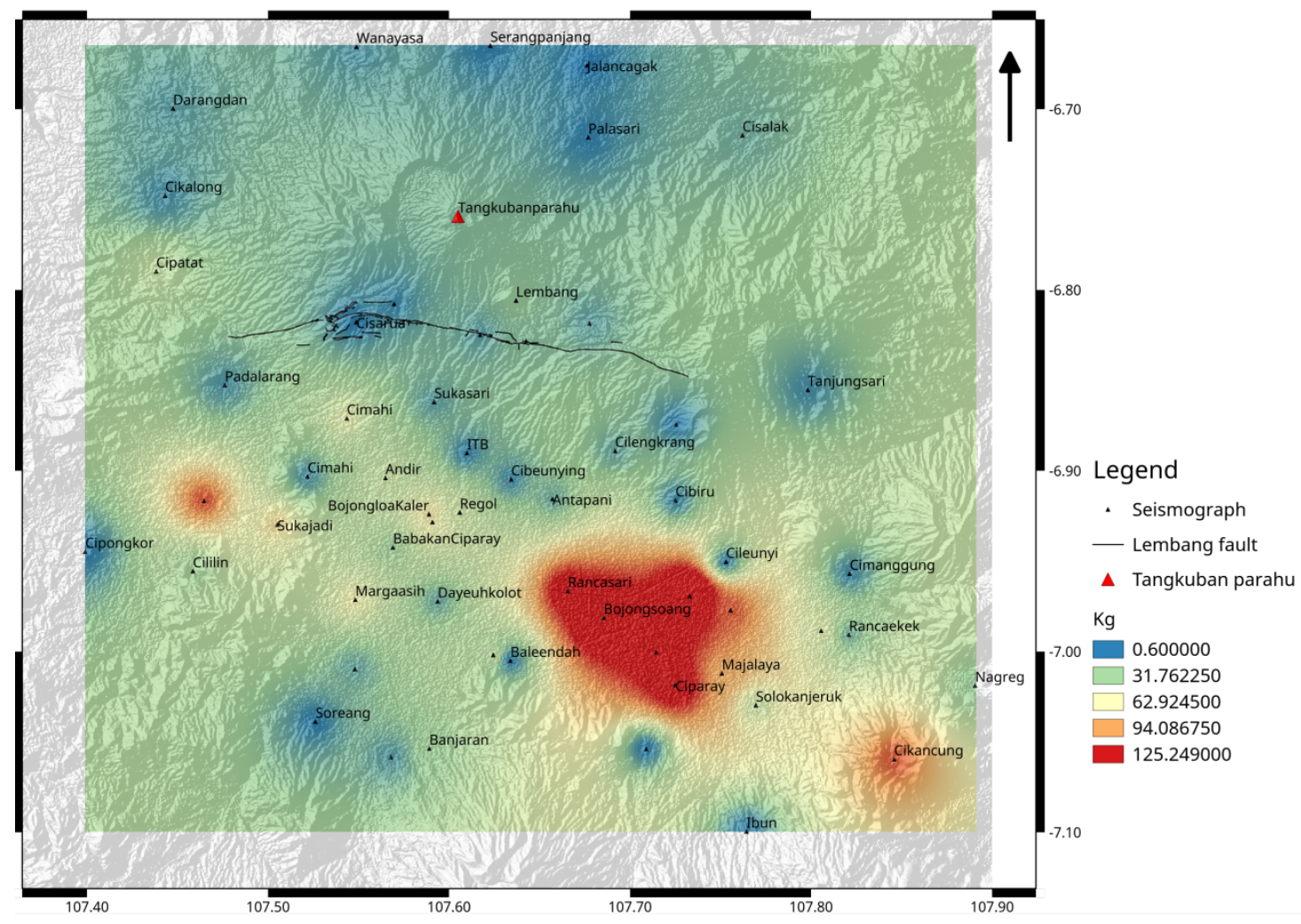

Figure 5. Seismic susceptibility index map $(\mathrm{Kg})$ in Bandung basin area. 